\title{
PERANGKAT KERAS JARINGAN KOMPUTER
}

\author{
Hafifah Anggriyani ( 0305192063 ) \\ Program Studi Pendidikan Matematika -3 \\ Fakultas Ilmu Tarbiyah Keguruan UIN Sumatera Utara \\ Jl. William Iskandar Pasar V, Medan Estate \\ Email : hafifahanggriyani2903@gmail.com
}

\begin{abstract}
Perangkat keras jaringan komputer adalah perangkat yang digunakan untuk menghubungkan komputer ke komputer lainnya dalam jaringan untuk tujuan berbagi data,berbagi informasi serta berbagi peripheral dalam jaringan. Jaringan komputer adalah sebuah sistem yang terdiri atas computer dan perangkat jaringan lainnya yang bekerja bersama-sama untuk mencapai suatu tujuan yang sama. komputer merupakan benda mati (alat) yang dapat digunakan manusia untuk membantu manusia juga dalam hal meringankan atau menyelesaikan pekerjaan-pekerjaannya.
\end{abstract}

Kata Kunci : hardware, jaringan komputer, informasi 


\section{BAB I \\ PENDAHULUAN}

\subsection{LATAR BELAKANG}

Perangkat keras komputer adalah semua bagian fisik komputer, dan dibedakan dengan data yang berada di dalamnya atau yang beroperasi di dalamnya, dan dibedakan dengan perangkat lunak (software) yang menyediakan instruksi untuk perangkat keras dalam menyelesaikan tugasnya.

Hardware dalam bahasa Indonesia disebut juga dengan nama "perangkat keras" yaitu salah satu komponen dari sebuah komputer yang sifat alatnya bisa dilihat dan diraba secara langsung atau yang berbentuk nyata, yang berfungsi untuk mendukung proses komputerisasi. Hardware dapat bekerja berdasarkan perintah yang telah ditentukan atau disebut juga dengan istilah "instruction set”.

Adanya perintah yang dapat dimengerti oleh hardware, maka hardware tersebut dapat melakukan berbagai kegiatan yang telah ditentukan oleh pemberi perintah. (Gambar perangkat keras komputer, 2012) Secara fisik, Komputer terdiri dari beberapa komponen yang merupakan suatu sistem. Sistem adalah komponenkomponen yang saling bekerja sama membentuk suatu kesatuan. Apabila salah satu komponen tidak berfungsi, akan mengakibatkan tidak berfungsinya prosesproses yang ada pada komputer dengan baik. Komponen komputer ini termasuk dalam kategori elemen perangkat keras (hardware). Berdasarkan fungsinya, perangkat keras komputer dibagi menjadi : Input divice (unit masukan); Process device (unit Pemrosesan); Output device (unit keluaran); Backing Storage ( unit penyimpanan); dan Periferal ( unit tambahan). (Perangkat Keras, 2012).

\subsection{RUMUSAN MASALAH}

1. Apa yang di maksud dengan Perangkat Keras komputer ?

2. Apa saja Sejarah Perangkat Keras komputer?

3. Apa saja Jenis-Jenis Komputer ?

4. Apa saja Sistem-sistem Komputer $?$

\subsection{TUJUAN PENULISAN}

1. Untuk mengetahui arti Pengertian dari Perangkat keras komputer

2. Untuk mengetahui Sejarah perangkat keras komputer

3. Untuk mengetahui Jenis-jenis Komputer

4. Untuk mengetahui Sistem-sistem Komputer 


\section{BAB II}

\section{PEMBAHASAN}

\subsection{PERANGKAT KERAS KOMPUTER}

\section{( HARDWARE )}

Komputer adalah serangkaian mesin elektronik yang terdiri dari jutaan komponen yang dapat saling bekerja sama, serta membentuk sebuah sistem kerja yang rapi dan teliti. Sistem ini kemudian digunakan untuk dapat melaksanakan pekerjaan secara otomatis, berdasarkan instruksi (program) yang diberikan kepadanya. Istilah Hardware komputer atau perangkat keras komputer, merupakan benda yang secara fisik dapat dipegang, dipindahkan dan dilihat. Software komputer atau perangkat lunak komputer merupakan kumpulan instruksi (program/prosedur) untuk dapat melaksanakan pekerjaan secara otomatis dengan cara

mengolah atau memproses kumpulan instruksi (data) yang diberikan.

Filosofisnya bahwa komputer merupakan benda mati (alat) yang dapat digunakan manusia untuk membantu manusia juga dalam hal meringankan atau menyelesaikan pekerjaan-pekerjaannya. Karena manusia adalah makhluk hidup sedangkan hardware dan software adalah benda mati, maka tujuan membuat atau menciptakan (create) hardware dan software tersebut adalah untuk kepentingan manusia, dalam hal ini istilah manusia adalah sebagai Brainware komputer.

\subsection{SEJARAH KOMPUTER}

\section{Generasi Pertama}

Tabung hampa udara (vacum-tube) merupakan ciri dari komputer generasi pertama dengan salah satu bahan bakunya terbuat dari kaca, sehingga mudah pecah dan mudah menyerap atau menyalurkan panas. Agar bahan dari kaca tadi tidak cepat panas, maka diperlukan komponen lain yang berfungsi sebagai pendingin. Dengan adanya komponen tambahan tersebut maka komputer menjadi besar, berat dan mahal. Sekitar tahun 1946, komputer elektronik di dunia yang pertama yakni ENIAC selesai dibuat. Pada komputer tersebut terdapat \pm 18.800 tabung hampa udara dan berbobot \pm 30 ton dengan panjang \pm 30 meter dan tinggi \pm 2,4 meter sehingga memerlukan ruangan yang luas dan lebar.

\section{Generasi Kedua}

Penemuan bahan baku lain berupa transistor yang terdiri dari basic, collector dan emmiter, merupakan ciri dari komputer generasi kedua ini. Transistor merupakan singkatan dari Transfer Resistor, sebagai komponen padat yang mempunyai banyak keunggulan seperti tidak mudah pecah, tidak cepat menyerap 
dan menyalurkan panas, maka dengan begitu komputer yang ada menjadi lebih kecil, lebih murah dan lebih sedikit membutuhkan listrik. Beberapa contoh komputer generasi kedua adalah : IBM Serie 1400, NCR Serie 304, MARK IV (diproduksi di Jepang tahun 1957), Honeywell Model 800 dan IBM 7090 (buatan Amerika).

\section{Generasi Ketiga}

Komputer generasi ketiga merupakan lanjutan riset dari generasi kedua dengan hasil riset bahwa transistor-transistor dapat dipadatkan (Integrated Circuit/IC). IC adalah gabungan dari ribuan transistor dalam bentuk silikium dengan bentuk kecil dan ukuran beberapa milimeter. Contoh komputer generasi ini adalah : Apple Computer, TRS Model 180 dan IBM $\mathrm{S} / 360$.

\section{Generasi Keempat}

Riset kemudian dilanjutkan lagi, pada generasi ini ditandai dengan munculnya LSI (Large Scale Integration) yang merupakan pemadatan ribuan IC kedalam sebuah Chip. Istilah chip digunakan untuk menunjukkan suatu lempengan persegi empat yang memuat rangkaian-rangkaian terpadu (integrated circuits). LSI kemudian dikembangkan dalam VLSI (Very Large Scale Integration). Perkembangan berikutnya ditandai dengan munculnya mikroprocessor dan semi konduktor. Perusahaan pembuat mikroprocessor antara lain : Intel Corporation, Motorola, Zilog dll. Intel Corp. Mengeluarkan mikroprocessor dengan model 4004, 8088, 80286, 80386, 80486, 80586 atau dikenal dengan nama pentium. Sedangkan pabrik Motorola mengeluarkan model 6502, 6800 .

\subsection{JENIS-JENIS KOMPUTER}

Sejarah perkembangan komputer dari generasi ke generasi memperlihatkan bagaimana perbedaan secara fisiknya. Bentuk Komputer berdasarkan jenisnya dibedakan berdasarkan golongan, kapasitas penyimpanan datanya dan data yang diolahnya.

\section{Berdasarkan Golongan}

- General Purpose Computer adalah komputer yang biasa atau yang umum digunakan untuk mengerjakan pekerjaan sehari-hari (rutinitas) seperti pekerjaan kantoran yang bervariasi.

- Special Purpose Computer adalah komputer yang digunakan untuk menyelesaikan pekerjaan ataupun aplikasi khusus. Special-purpose pada awalnya merupakan general-purpose yang digunakan secara

khusus dan disesuaikan dengan konfigurasi ataupun peralatan didalamnya yanng sudah dimodifikasi.

\section{Berdasarkan Kapasitas}


- Komputer Mikro (Personal Computer) diciptakan untuk memenuhi

kebutuhan perorangan (personal). Memori yang dimiliki oleh sebuah

personal komputer pada awalnya hanya berkisar antara 32 hingga

64 KB (Kilo Byte). Tetapi dalam perkembangannya memori sebuah personal komputer sampai diatas $128 \mathrm{MB}$ (Mega Byte). Contoh

dari komputer mikro ini seperti workstation desktop atau tower, laptop, notebook dll.

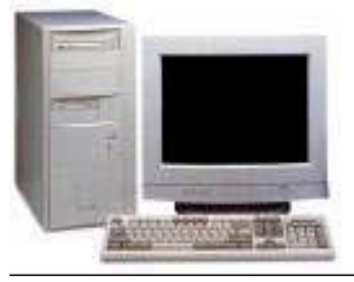

Gambar 2. Personal Komputer

- Komputer mini mempunyai kemampuan beberapa kali lebih besar jika dibanding dengan personal komputer. Hal ini disebabkan karena mikroprocessor yang digunakan untuk memproses data memang mempunyai kemampuan jauh lebih unggul jika dibandingkan dengan mikroprocessor yang digunakan pada personal komputer.

Ukuran fisiknya dapat sebesar lemari kecil. Komputer mini pada umumnya dapat digunakan untuk melayani lebih dari satu pemakai (multiuser). Dalam sistem multiuser ini, pada akhirnya personal komputer banyak digunakan sebagai terminal yang berfungsi untuk memasukkan data. Contoh komputer mini : IBM AS-400.

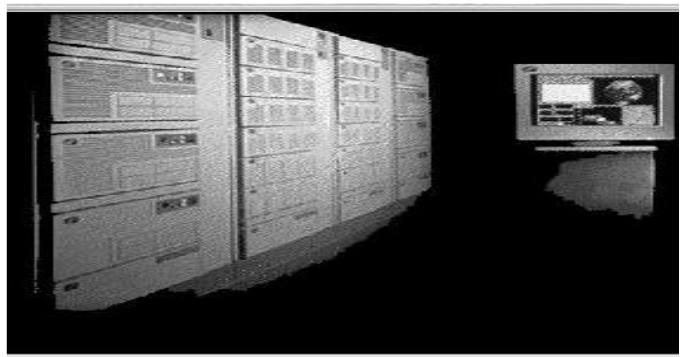

Gambar 3. Mini Komputer

- Komputer mainframe adalah yang memiliki processor lebih dari satu. Dengan demikian, dari segi kecepatan proses mainframe jauh lebih cepat jika dibanding dengan mini komputer. Kecepatan kerja mainframe mencapai 1 milyar operasi perdetik (1 giga operations per-seconds $=1$ GOPS). Kecepatan ini sangatlah diperlukan, karena mainframe biasanya digunakan untuk memproses data yang mempunyai kapasitas sangat besar dan disamping itu mainframe biasanya juga digunakan oleh puluhan hingga ratusan pemakai yang bekerja secara bersama-sama. Contoh komputer mainframe adalah z900. 


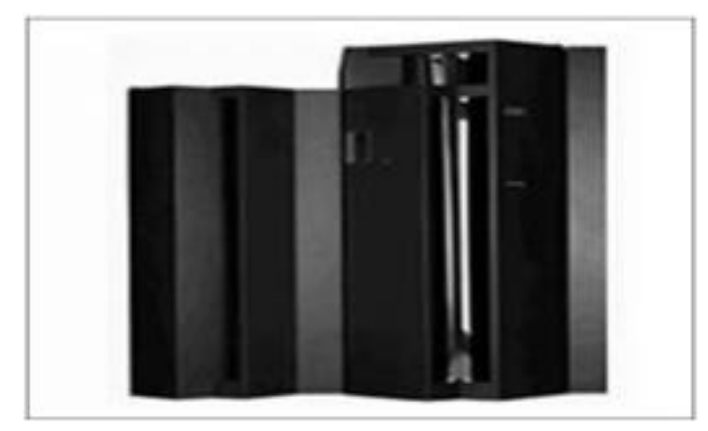

Gambar 4. Komputer mainframe

- Komputer Super, sesuai dengan namanya memiliki kemampuan, yaitu kecepatan proses yang tinggi serta memiliki kemampuan menyimpan data yang jauh lebih besar apabila dibandingkan dengan mainframe. Harga super komputer sangatlah besar dan mahal. Salah satu contoh super komputer adalah Cray-2. Pengguna super komputer biasanya negara-negara yang sudah maju ataupun perusahaanperusahaan yang sangat besar, seperti misalnya industri pesawat terbang Nurtanio. Kemampuan lain yang dimiliki oleh super komputer adalah mampu membaca/menyadap pelbagai data dari satelit.

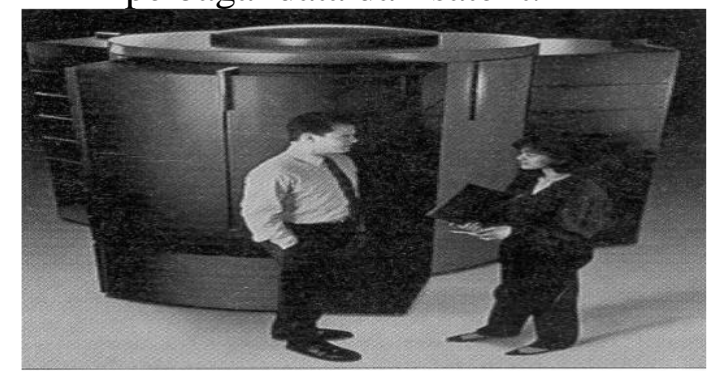

Gambar 5. Komputer Super

\section{Berdasarkan Data yang Diolah}

Data yang diolah oleh komputer jenisnya sangatlah banyak. Ada data berupa gambar, suara, huruf, angka, keadaan, simbol ataupun yang lainnya lagi. Dalam hal ini, tidak setiap komputer bisa mengolah seluruh data yang ada. Ada komputer yang hanya bisa mengolah suara, ataupun hanya mengolah huruf dan angka saja. Walaupun demikian, ada pula komputer yang bisa mengolah beberapa data secara bersama-sama.

- Digital Computer, merupakan suatu komputer yang dapat digunakan untuk mengolah data yang bersifat kuantitatif (sangat banyak jumlahnya). Datanya berupa simbol yang memiliki arti tertentu, misalnya : simbol alphabetis yang digambarkan dengan huruf $\mathrm{A}$ s/d $\mathrm{Z}$ ataupun a s/d $\mathrm{z}, \quad$ simbol numerik yang digambarkan dengan angka $0 \mathrm{~s} / \mathrm{d} 9$ ataupun simbol-simbol khusus, seperti halnya : ? / * \& !.

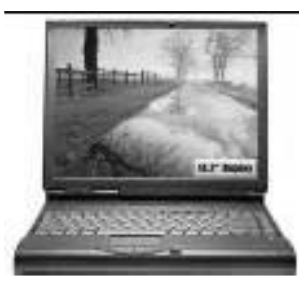

Gambar 6. Digital Komputer

- Analog Computer, merupakan suatu komputer yang dapat digunakan untuk mengolah data yang bersifat kualitatif. Data yang ada bukan merupakan simbol, tetapi masih merupakan suatu kejadian. Seperti misalnya keadaan suhu ataupun kelembaban udara, ketinggian ataupun kecepatan adalah merupakan suatu keadaan yang oleh komputer 
kemudian ditetapkan sehingga

menjadi suatu ukuran.

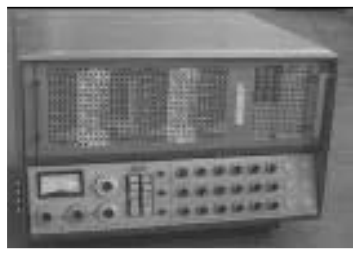

Gambar 7. Komputer Analog

- Hybrid Computer, merupakan komputer yang bisa digunakan untuk mengolah data yang bersifat kuantitatif ataupun kualitatif. Hibrid komputer juga bisa dikatakan sebagai gabungan dari analog dan digital komputer. Komputer ini banyak digunakan oleh pelbagai rumah sakit yang digunakan untuk memeriksa keadaan tubuh dari pasien, yang pada akhirnya, komputer bisa mengeluarkan pelbagai analisa atau hasil diagnosa yang disajikan dalam bentuk gambar, grafik ataupun tulisan.

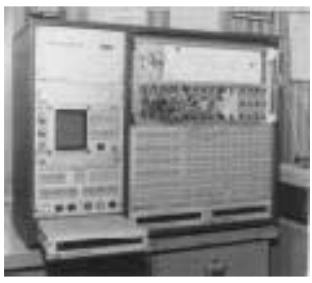

Gambar 8. Komputer Hybrid

\subsection{SISTEM-SISTEM KOMPUTER}

Berdasarkan sifat dan kegunaannya perangkat keras computer (hardwarecomputer) dapat dikelompokan menjadi 4 bagian :
A. Perangkat input
B. Perangkat keluaran
C. Perangkat proses; dan
D. Perangkat penyimpanan

\section{- Perangkat Input}

Perangkat input adalah alat yang digunakan untuk memasukan data untuk diolah oleh computer. Contoh alat input computer adalah sebagai berikut :

a. Keyboard

Keyboard adalah sebuah papan kunci yang terdiri dari deretan huruf dan angka.

\section{Keyboard QWERTY}

Keyboard QWERTY adalah keyboard yang susunan hurufnya diambil dari susunan huruf QWERT yang berada di sebelah kiri.Tata letak ini ditemukan oleh Scholes, Glidden dan Soule pada tahun 1878, dan kemudian menjadi standar mesin tik komersial pada tahun 1905. Keyboar QWERTY memiliki beberapa tombol yaitu tombol fungsi,tombol alfanumerik, tombol control dan tombol numerik.

\begin{tabular}{|c|c|c|c|c|c|c|c|c|c|c|c|c|c|c|}
\hline$=1 !$ & 13 & 2 & $\begin{array}{l}\# \\
3 \\
\end{array}$ & $\begin{array}{l}5 \\
4\end{array}$ & $\frac{9}{5}$ & & $\hat{n}$ & $\begin{array}{l}8 \\
7\end{array}$ & 8 & & 9 & \begin{tabular}{l|l} 
& $=$ \\
0 & $=$
\end{tabular} & 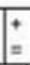 & Delete \\
\hline $\mathrm{Tab}$ & Q & W & $\mathrm{E}$ & & $R$ & $T$ & & $Y$ & $U$ & 1 & 0 & $P$ & & 1 \\
\hline Caps & A & & $\mathrm{S}$ & D & $F$ & G & & $\mathrm{H}$ & $\mathrm{J}$ & K & L & & , & Enter \\
\hline Shift & & Z & $x$ & C & 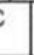 & V & B & $\mathrm{N}$ & M & $\mathrm{M}$ & 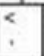 & $\begin{array}{l}> \\
?\end{array}$ & & Shift \\
\hline $\mathrm{Ctrl}$ & & & Alt & & & & & & & & & Alt & & Ctrl \\
\hline
\end{tabular}

Gambar 1 Keyboard QWERTY 


\section{Keyboard DVORAK}

Keyboard DVORAK (1932) adalah keyboar yang susunan hurufnya lebih menekankan ppekerjaan pada tangan kiri biasanya susunan huruf vokal berada disebelah kiri.

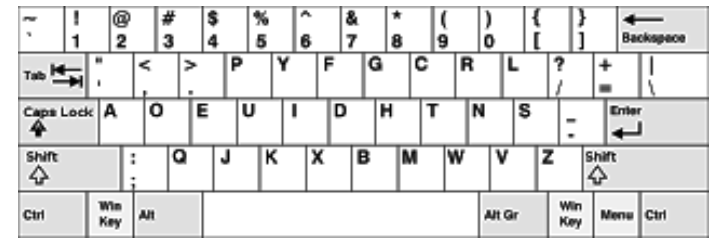

Gambar 2 Keyboard DVORAK

\section{Keyboard KLOCKENBERG}

Keyboard adalah keyboard yang susunan hurufnya di pisah antara susunan huruf sebelah kiri dan susunan huruf sebelah kanan.

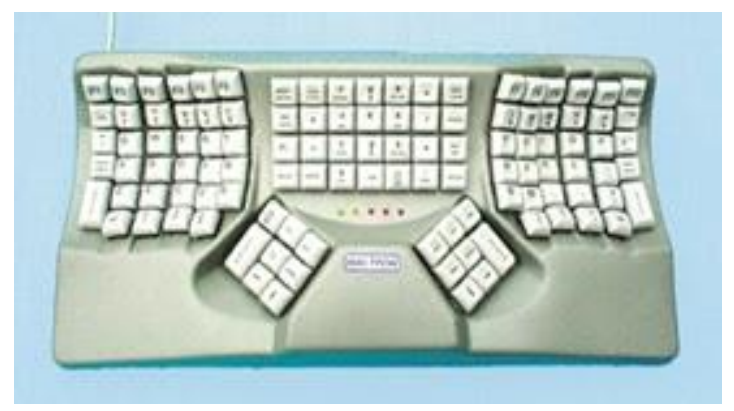

\section{Gambar 3 Keyboard KLOCKENBERG}

4. Keyboard Maltron

keyboard yang di produksi oleh perusahaan MALTRON dengan desain agak cembung kedalam.

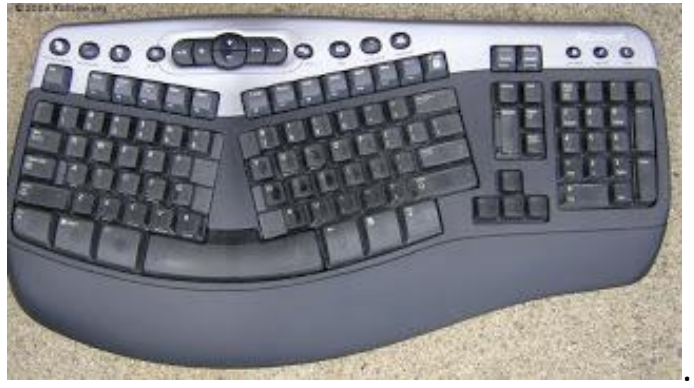

Gambar 4 Keyboard Maltron keyboard Alphabetik adalah Keyboard yang susunan hurufnya berdasarkan susunan huruf alpabet.

\begin{tabular}{|l|l|l|l|l|l|l|l|l|l|l||}
\hline this 1 s an alphabetic keyboard \\
\hline a & b & c & d & e & f & g & h & i & j \\
\hline k & l & m & n & o & p & q & r & s \\
\hline
\end{tabular}

Gambar 5 Keyboard Alpahbetik

6. Keyboard Numeric

keyboard numeric adalah keyboard yang hanya berisi susunan angka untuk di inputkan pada komputer.

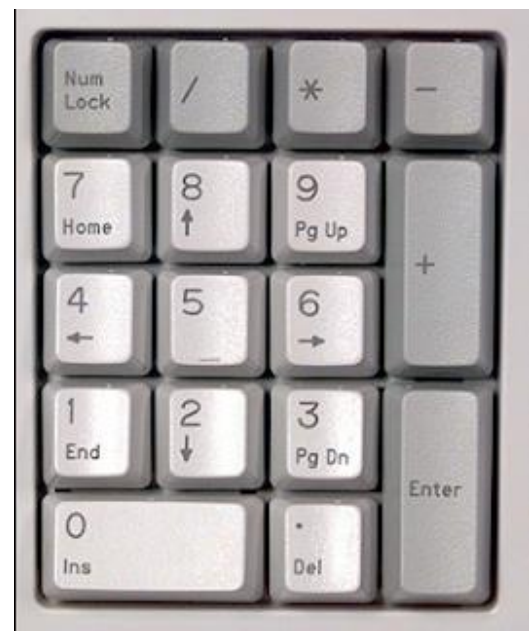

Gambar 6 Keyboard Numeric

b. Mouse / tetikus

Mouse adalah alat yang digunakan untuk menggerakan kursor dan menunjuk aplikasi program pada layar monitor.

- $\quad$ Mouse USB

5. Keyboard Alphabetik 


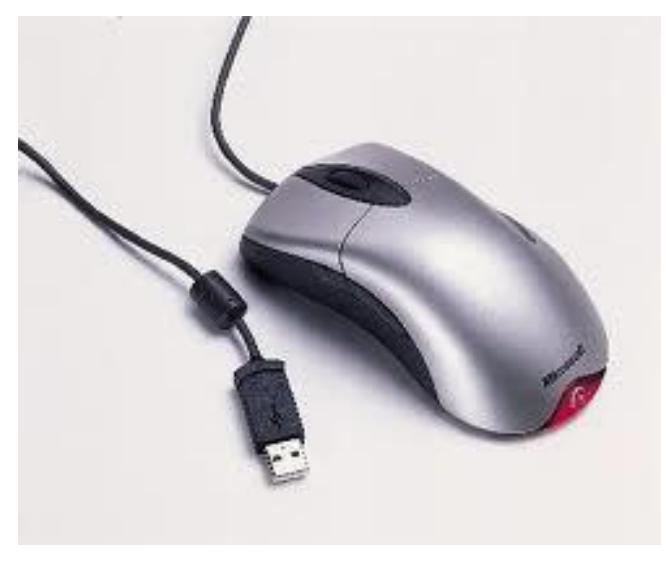

Gambar 9 Mouse USB

\section{c. Scanner}

Scanner adalah alat yang digunakan untuk merubah teks atau gambar menjadi teks atau gambar digital untuk di olah di computer.

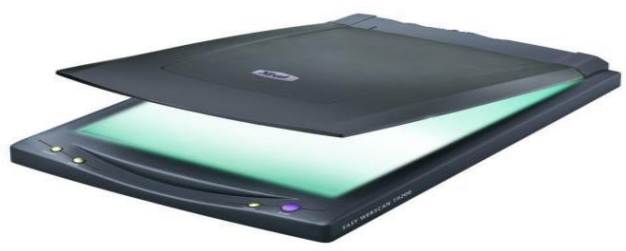

Gambar 10 Scanner

\section{d. Optical Drive}

Optical drive adalah alat untuk membaca kepingan CD dan DVD.

Optical Drive sendiri terdiri dari 5 jenis yaitu:

\section{CD ROM Drive}

CD ROM adalah alat yang digunakan untuk membaca CD (Compact Disc) dan VCD.

\section{CD RW Drive}

CD RW Drive adalah alat yang digunakan untuk membaca dan menulis CD pada computer.

\section{DVD ROM Drive}

DVD ROM Drive adalah alat yang digunakan untuk membaca $\mathrm{CD}$, VCD dan DVD pada computer.

\section{DVD Combo Drive}

DVD Combo Drive adalah alat yang digunakan untuk membaca CD dan DVD dan hanya bias menulis CD pada computer.

\section{DVD RW Drive}

DVD RW Drive adalah alat yang digunakan untuk membaca dan menulis CD dan DVD pada computer.

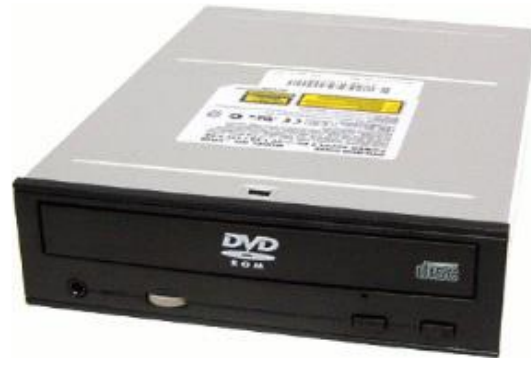

Gambar 11 Optical Drive

\section{e. Joystick}

Joystick atau tuas control adalah alat yang digunakan untuk menggerakan kursor ke segala arah biasanya digunakan untuk permainan computer.

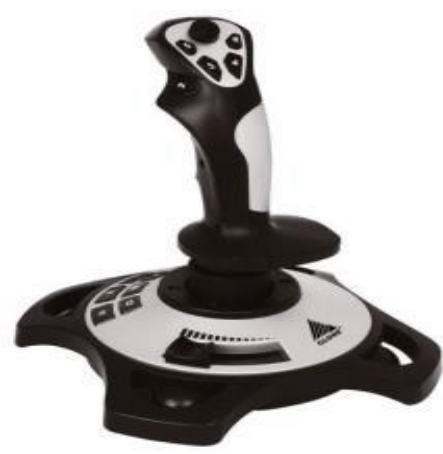

Gambar 12 Joystick 
f. Floppy Disk Drive

FDD adalah alat yang digunakan untuk

membaca dan merekam data dengan media penyimpanan disket.

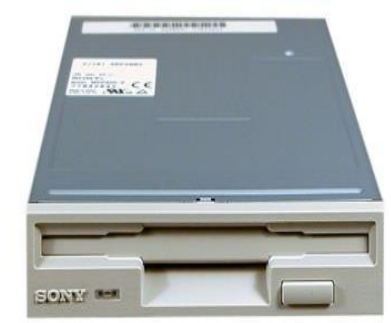

Gambar 13 Floppy Disk

\section{- Perangkat Output}

Alat output adalah alat yang digunakan untuk menampilkan hasil dari proses pengolahan pada CPU. Contoh alat output computer adalah sebagaia berikut

a. Monitor

Monitor adalah alat yang digunakan untuk menampilkan hasil pengolahan data berupa grafis.

- Monitor CRT (Cathode ray Tube)

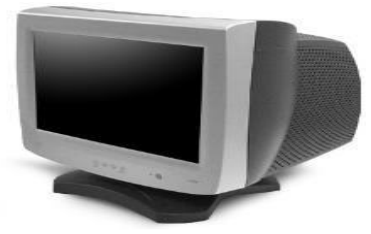

Gambar 14 Monitor CRT

\section{b. Printer}

Printer adalah alat yang digunakan untuk mencetak hasil pengolahan pada komputer menjadi hardcopy.

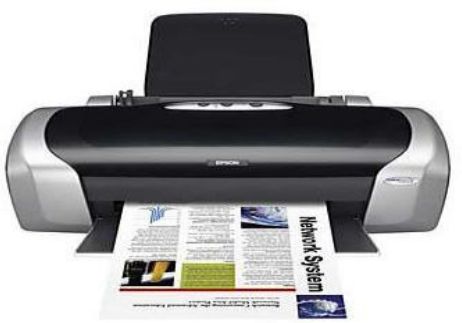

Gambar 15 Printer Inkjet

\section{Prangkat Proses}

Alat proses adalah alat yang digunakan untuk melakukan pengolahan data pada computer.

Berikut adalah alat-alat proses yang ada pada computer :

a. Processor

Processor adalah sebuah chip yang berfungsi untuk mengontrol dan mengolah data pada computer.

1. Intel

Untuk processor intel ini terdapat beberapa jenis processor yaitu :

- Intel 286, 386, 486

- Pentium MMX, II, III, IV, Celeron

- Pentium IV LGA, Dual Core, Core 2 Duo

- Pentium M, Centrino, Centrino Duo, Atom, Atom Dual Core

- Quad Core, Core i3, Core i5, Core i7

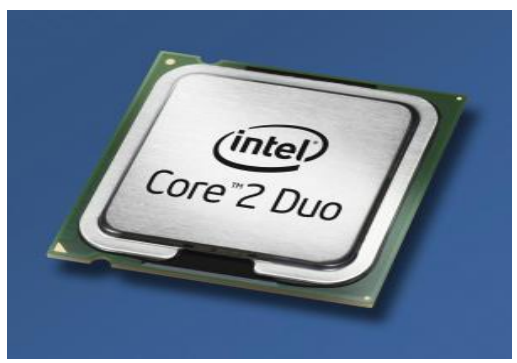


Gambar 16 Processor Intel

\section{b. Motherboard}

Motherboard adalah sebuah papan induk dimana semua komponen alat proses di install kan.

Istilah singkatan yang ada pada motherboard :

$\mathrm{AGP}=$ Accelerated Graphic Port

$\mathrm{PCI}=$ Perpheral Component Interconect

BIOS= Basic Input Output System

CMOS $=$ Complementary Metal Oxid

Semiconductor

$\mathrm{CNR}=$ Communication Network Rise

ISA = Industry Standard Architecture

SATA $=$ Serial Advance Technology

Attachment

$\mathrm{IDE}=$ Integrate Drive Electronic

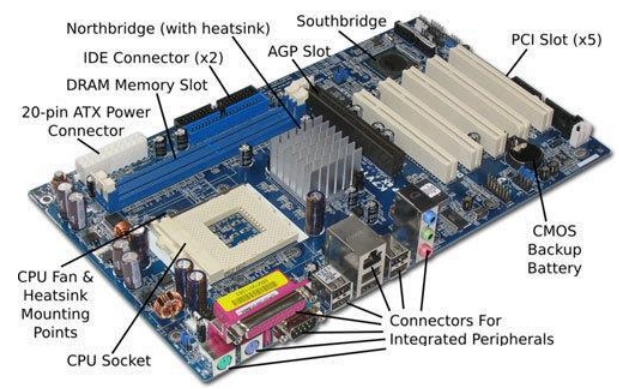

1. Soket Prosesor yaitu tempat dimana processor dipasangkan.

2. Slot Memori yaitu tempat dimana memoru utama dipasangkan.

3. Northbridge, berfungsi untuk mengatur lalu lintas data antara prosesor dengan sistem memori.

4. Southbridge, berfungsi untuk menghubungkan dan mengontrolinput, output antara, processor, RAM, perangkat penyimpanan dan periferal lainnya.

5. Slot PCI Express x16, yaitu slot yang bisa dipasang VGA Card generasi terbaru

6. Slot AGP, yaitu slot yang digunakan khusus untuk VGA Card.

7. Baterai CMOS, yaitu baterai yang berfungsi untuk memberikan daya pada BIOS.

8. Port SATA, interface generasi terbaru yang bias digunakan untuk Gambar 17 Motmerbgarlpungkan Hard Disk, Optical drive Yang perlu di perhatikan adalah antara dengan system computer.

motherboard untuk processor intel dan processor AMD adalah berbeda. Karena setiap motherboard dibuat khusus untuk processor tertentu.

Komponen-komponen yang umumnya ada dalam sebuah motherboard adalah sebagai berikut :
9. Port IDE, yaitu teknologi sebelum SATA memiliki fungsi yang sama seperti SATA

10. Port Floppy Disk, yaitu port yang digunakan menghubungkan floppy disc driver dengan motherboard. 
11. Port Power, yaitu port digunakan untuk memberikan daya kepada system computer.

\section{c. RAM (Random Acces Memory)}

RAM adalah sebuah memori yang bersifat volatile (sementara) yang berfungsi membantu kecepatan eksekusi pada pengolahan data. Semakin tinggi RAM yang digunakan maka semakin baik pula computer akan berjalan. Jenis-jenis RAM adalah sebagai berikut :

\section{EDO RAM}

RAM jenis ini pertama kali diciptakan pada tahun 1995 memiliki 72 pin dengan kecepatan clock $50 \mathrm{MHz}$ biasa digunakan pada Pentium 100.

\section{SDRAM}

SDRAM (Sychronous Dynamic Random Acces Memory) adalah jenis RAM yang banyak digunakan pada computer Pentium II dan III. Memiliki 168-pin dengan kecepatan PC66, PC100,PC133.

\section{DDR RAM}

Double Data Rate Random Acces Memory adalah jenis RAM yang banyak digunakan pada Pentium IV. Memiliki 184 pin dengan kecepatan PC-1600, PC-2100, PC2700, PC-3200, PC-3700, PC-4200.

\section{DDR2 RAM}

Double Data Rate 2 Random Acces Memory adalah jenis RAM yang biasa digunakan pada Pentium Dual Core dan Core 2 Duo. Memiliki 240 pin dengan kecepatan PC2-3200, PC2- 4200, PC25300, PC2-6400, PC2-8500.

\section{DDR3 RAM}

Double Data Rate 3 Random Acces Memory adalah jenis RAM yang biasa digunakan pada Pentium Quad Core, Core i3, Core i5, dan Core i7. Memiliki 240 pin dengan kecepatan PC3- 6400, PC3-8500, PC3-10666, PC3-12800, PC3-14500, PC316000, PC3-17000.

Lalu apa yang membedakan antara DDR RAM, DDR2 RAM dan DDR3 RAM secara fisik? kita dapat melihat gambar perbandingannya sebagai berikut :

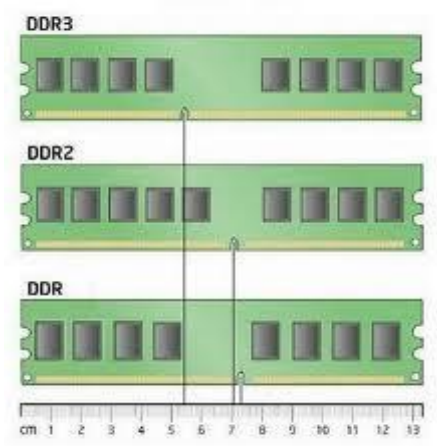

Gambar 18 Perbandingan RAM

\section{d. VGA}

Video Graphic Adapter adalah perangkat keras computer yang berfungsi untuk mengolah grafis pada computer. Semakin tinggi resolusi suatu VGA makan tampilan akan semakin baik. VGA pertama kali di produksi dan dipasarkan oleh IBM pada tahun 1987. 


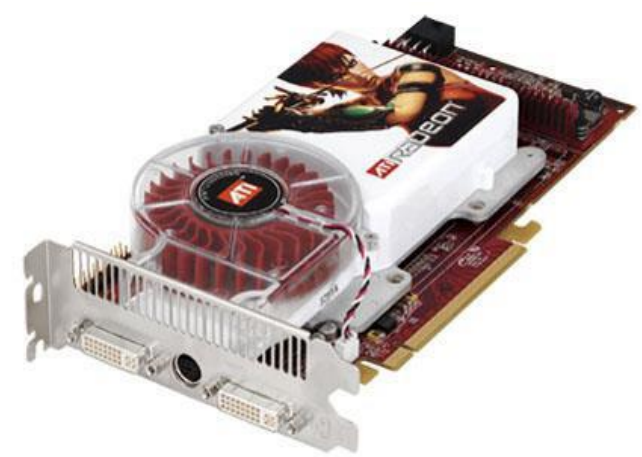

Gambar 19 VGA Card

\section{e. Power Supply}

Power supply adalah suatu perangkat keras computer yang berfungsi memasok daya listrik ke seluruh komponen perangkat keras computer.

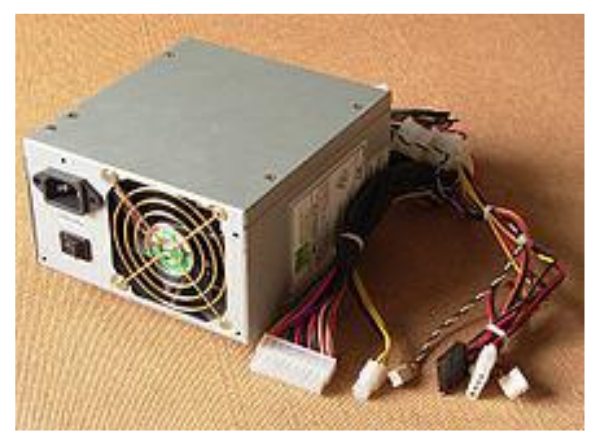

Gambar 20 Power Supply

- Perangkat Penyimpanan

Alat penyimpanan adalah alat yang digunakan untuk menyimpan data hasil dari suatu pengolahan agar dapat kembali dibuka jika diperlukan.

Berikut adalah media penyimpanan yang sering digunakan pada computer :

\section{a. Disket}

Disket adalah media penyimpanan yang terbuat dari bahan yang bersifat magnetic.

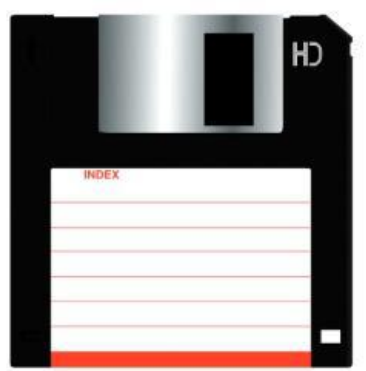

Gambar 21 Disket

Disket memiliki ukuran: 8 inchi, 5.25 inchi dan 3.5 inchi. Kapasitas disket bisa dilihat dari label yang tertulis, misalnya:

- DD (Double Density), untuk disket 5.25 inchi mempunyai kapasitas $360 \mathrm{~KB}$, dan disket 3.50 inchi mempunyai kapasitas 720 $\mathrm{KB}$.

- DHD (High Density)Disket ukuran 5.25 inchi kapasitasnya 1.2 MB, dan untuk dikset 3.50 inchi kapasitasnya 1.4 MB.

\section{- ED (Enchanced High Density),} mempunyai kapasitas 2.8 MB. Dan memiliki ukuran 3.50 inchi.

density adalah kerapatan dalam menyimpan data semakin tinggi density yang dimiliki oleh sebuah disket maka semakin besar pula daya tampung yang dimiliki.

b. Optical Disc

Optical disc adalah media penyimpanan yang dapat menampung data cukup besar biasanya optical disc menggunakan media penyimpanan CD (Compact Disc) yang memiliki kapasitas penyimpanan sekitar 700 MB dan DVD (Digital Video Disc) 
memiliki kapasitas penyimpanan sekitar 4.7 GB.

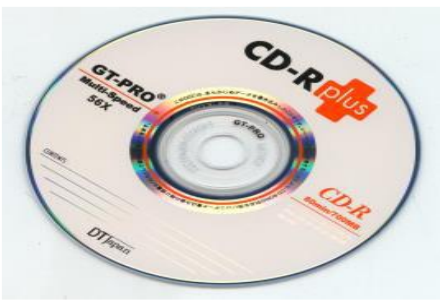

Gambar 22 CD

c. Flashdisk

Flashdish adalah media penyimpanan yang sangat popular dikalangan masyarakat saat ini selain praktis dan mudah digunakan flashdish dapat menampung data yang cukup besar dari 512 MB, 1 GB, 2 GB, 4 GB sampai sekarang masih terus berkembang.

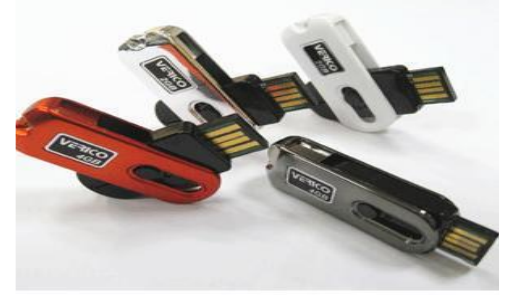

Gambar 23 Flashdisk

\section{d. HDD}

Hardisk Drive adalah media penyimpanan utama yang digunakan pada computer dengan kapasitas penyimpanan yang sangat tinggi dan bersifat non volatile.

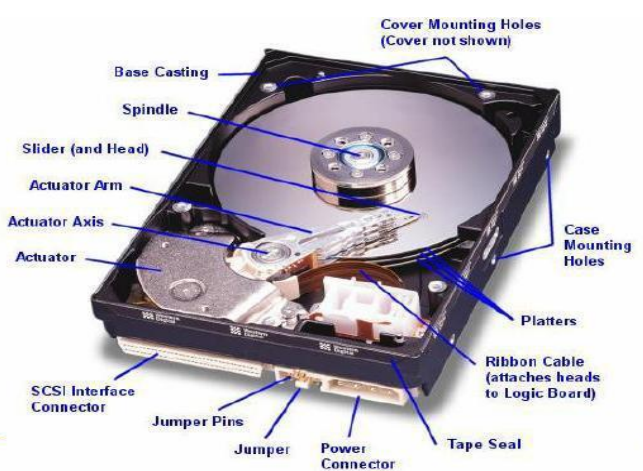

Gambar 24 Bagian Dalam Hardisk

\section{BAB III \\ PENUTUP}

\subsection{KESIMPULAN}

Berdasarkan uraian materi yang terdapat dalam bab pembahasan, dapat diambil kesimpulan:

Komputer adalah serangkaian mesin elektronik yang terdiri dari jutaan komponen yang dapat saling bekerja sama, serta membentuk sebuah sistem kerja yang rapi dan teliti. Sistem ini kemudian digunakan untuk dapat melaksanakan pekerjaan secara otomatis, berdasarkan instruksi (program) yang diberikan kepadanya. Istilah Hardware komputer atau perangkat keras komputer, merupakan benda yang secara fisik dapat dipegang, dipindahkan dan dilihat. Software komputer atau perangkat lunak komputer merupakan kumpulan instruksi (program/prosedur) untuk dapat melaksanakan pekerjaan secara otomatis dengan cara

mengolah atau memproses kumpulan instruksi (data) yang diberikan. 
Hardware memiliki beberapa komponen yang terbagi berdasarkan fungsinya, meliputi : Input device (unit masukan); Process device (unit Pemrosesan); Output device (unit keluaran); Backing Storage ( unit penyimpanan); dan Periferal ( unit tambahan). Fungsi komponen hardware, yaitu: Input device : Unit ini berfungsi sebagai media untuk memasukkan data dari luar ke dalam suatu memori dan processor untuk diolah guna menghasilkan informasi yang diperlukan. Process device : Unit ini berfungsi sebagai tempat pemroses instruksi-instruksi program yang ada pada komputer dan mengontrol keseluruhan sistem komputer selama pengolahan data berlangsung. Output device : Unit ini berfungsi sebagai alat yang menampilkan hasil pengolahan data yang dilakukan CPU. Storage device : Unit ini berfungsi sebagai tempat penyimpanan data atau program yang dapat digunakan kembali pada waktu tertentu. Periferal device : Unit ini berfungsi sebagai perangkat tambahan yang digunakan sesuai dengan kebutuhan.

\section{Referensi}

Yahfizham.2019. Dasar-dasar komputer. Medan. Perdana Publishing

Hasnul Arifin,2011. Kitab Suci Teknisi Komputer.Yogyakarta:PenerbitMediakom Sutono, 2010. Perangkat Keras Komputer Dan Tools Pendukungnya.Bandung: Penerbit Modula

Irawan, 2008Merakit Komputer Untuk Orang Awam. Palembang: Penerbit Maxikom

http://belajar-komputer-

mu.com/pengertian-hardware-perangkatkeras-komputer/ http://id.wikipedia.org/wiki/Perangkat_ker as http://artofdigital.net/find-the-bestcomputer-hardware.html http://www.anneahira.com/jenis-jeniskeyboard.htm http://silenceteller.wordpress.com/2010/08 /19/jenis-jenis-keyboard-papan-ketik/ www.youtube.com www.google.co.iddengan kata kunci "Merakit komputer", "Hardware Komputer", "Keyboard", "LCD”, “CPU” dll. 